\title{
ユーザの好みに基づく音楽アーティスト推奨システム Music Artist Recommendation System Based on User's Tastes
}

\author{
岡田 吉史 ${ }^{*, \dagger}$ 澤井 政宏 ${ }^{\ddagger}, \quad$ 楠芳之 ${ }^{*}$, 長島 知正 ${ }^{\ddagger, \|}$ \\ Yoshifumi OKADA Masahiro SAWAI \\ Yoshiyuki KUSUNOKI and Tomomasa NAGASHIMA
}

Web 上のオンラインショップの増加に伴い，ユーザの嗜好性に基づいて商品や情報を推奖 するシステムが提案されている。しかしながら，それらは個々のユーザが，商品や情報のど の特徴や性質に着目して好んでいるか，寸なわち “喏好理由(こだわり)”を考慮するもので はなかった。

本研究では，音楽アーティスト推奨を例に，ユーザの“好きなアーティスト”と“その嗜 好理由”に基づき，ユーザの好みに合うと思われるアーティスト推奨法を提案し，その実装 システムの開発を行った，本システムは，同時に好まれるアーティスト (と，それらに対する 嗜好理由)の関係を表す相関ルールを格納したデータベースを持つ。本論文では，テストクエ リを用いた評価実験をと拈して，1) 喏好理由の導入がアーティストのランキング精度に効果 的に働くこと，2) 従来の相関ルールに基づく推奨手法に比較して高い推奨精度を持ち，3）少 ない計算量で推奨可能である,ことを示す。

It is important to develop information systems which are capable of recommending user information or items reflecting user's individual tastes. We propose a music artist recommendation system that provides user with music artists who are the candidates being fit with user's tastes, and are derived from inference based on "favorite music artists" and "reasons to prefer them". Our system consists of an interface for recommendation and a database storing association rules that are patterns of relations among music artists who are liked by people concurrently. The characteristic of our system is to consider individual differences of reasons to prefer music artists in the recommendation processes. The performance of our system shows that reasons to prefer music artists have an effect on ranking recommended music artists, and that our system is superior to other systems in the recommendation accuracies and computational time.

\section{1 はじめに}

近年, Web 上のオンラインショップ[1][2]の 増加に伴って，個人の趣味嗜好に合った商品 や情報 (以下，アイテムと呼ぶ)の推奨を目的 とするシステムが提案されている ${ }^{[3-5]}$. その ような推奨システムは, ユーザ毎の各アイテ

\footnotetext{
*室蘭工業大学サテライト・ベンチャ一・ビジネス・ラ ボラトリー

Satellite Venture Business Laboratory, Muroran Institute of Technology

† okada@mail.svbl.muroran-it.ac.jp

‡室蘭工業大学 情報工学科

Computer Science and Systems Engineering, Muroran Institute of Technology
}

ムに対する評価点 (例えば 5 段階評価など) の プロファイルや購買履歴などのログ情報を蓄 積したデータベースを持ち, そこから推奖要 求ユーザと興味や嗜好が似た他のユーザを探 し，その人たちが好んでいるアイテムを推奨 する。しかし，ユーザ間の嗜好の類似性は， ユーザのアイテムの選好履歴 (どのアイテム をどの程度好んできたか) から計算されてお り，個々のユーザがアイテムのどのような特 徵や性質に着目して好んでいるかについては 考慮されてこなかった。

\footnotetext{
$\S$ sawai@sunta.csse.muroran-it.ac.jp

Tusunoki@mail.svbl.muroran-it.ac.jp

nagasima@epsilon2.csse.muroran-it.ac.jp
} 
一般に, 複数ユーザが同じアイテムを同程 度に好む場合でも，それらユーザの“嗜好性”, すなわち墸好理由や評価基準は多かれ少なか れ異なっている，既存の推奖システムは, 個々 のユーザの感性的相違を表していると考えら れる，アイテムへの“こだわり”の理由を区別 できないため，実際には嗜好性が全く異なっ ているユーザを，好みが似ていると判断する 可能性がある。より個人の嗜好に合わせたア イテム推奨を実現するためには，ユーザの選 好履歴のみでは不十分であり，アイテムの持 つ様々な特徵に対する嘹好理由の個人差を考 慮することが必要と考えられる。

本論文では，音楽アーティスト (以下アー ティスト) 推奨を例にとり，ユーザの“好きな アーティスト”と“その嗜好理由”に基づい て，ユーザの好みに合ったアーティストを推 奨する万法を提案し，その実装システムにつ いて述べる，我々は多数の人々によって同時 に好まれるアーティストの関係を相関ルール で表し，さらに，それらの相関ルールにアー ティストに対する嗜好理由を表す情報を導入 する。相関ルールは, 共起関係に着目して膨大 なデー夕に内在する規則性を表現するための 記述形式であり，例えば，スーパマーケットの POS データ (トランザクションデータベース) から同時に売れる商品 (アイテム)のパターン を分析するために用いられている[6]. 本論文 で提案するシステムは，1) 相関ルールに基づ くアーティストの嗜好パターン (以下, アー ティスト相関ルールと呼ぶ) を格納したデー タベースと，そこから 2) ユーザの好みに合 う候補アーティストを検索して提示する推奨 モジュールから構成される. 以下, 本論文で は，2 章で相関ルールに基づくアーティスト 推奨について述べ, 3 章ではアーティスト相 関ルールデータベースの構築方法とアーティ ストの推奨方法 (推奨モジュールの処理内容) を説明する．4 章では本システムの実行例を 示し， 5 章において本システムの推奨精度お よび計算量に関する評価結果と考察を述べる. 6 章は本論文のまとめである。

\section{2 相関ルールに基づくアーティスト 推奖}

前章で述べたように, 従来の推奨システム の多くは，ユーザ毎の嗜好情報として選好履 歴を用いているが, 本システムは, 人々によっ て同時に好まれる傾向が高いアーティストを 相関ルールで記述し，これに基づいてユーザ の好みに合うと思われるアーティストを導出 する．以下， 2.1 節では一般的な相関ルールの 定義を述べ, 2.2 節ではアーティスト相関ルー ルについて説明する。 2.3 節では相関ルール に基づくアーティスト推奨の利点を述べる。

\section{1 相関ルール}

アイテム全体の集合を $I=\left\{i_{1}, i_{2}, \ldots\right.$, $\left.i_{m}\right\}$, トランザクションデータベースを $D=$ $\left\{t_{1}, t_{2}, \ldots, t_{n}\right\}$ とする. 各トランザクション $t_{j}$ は，アイテム集合 $I$ の部分集合である，導 出される相関ルールは $X \Rightarrow Y(X, Y \subseteq I$, $X \cap Y=\emptyset)$ で表される。ここで, 相関ルール の左辺 $X$ を条件部, 右辺 $Y$ を結論部と呼ぶ. 相関ルールは, 支持度 (support) および確信 度 (confidence) と呼ばれる 2 つのパラメータ を持ち,これらの值によりルールの重要性が 見積もられる，支持度と確信度は，それぞれ 以下の式で表される。

支持度 $=\frac{X \text { と } Y \text { を共に含むトランザクション数 }}{D \text { 中の全トランザクション数 }}$

確信度 $=\frac{X \text { と } Y \text { を共に含むトランザクション数 }}{X \text { を含むトランザクション数 }}$

相関ルールマイニングは, 予めユーザによっ て指定される最小支持度と最小確信度を満た す全ての相関ルールを見つけることであり， 以下の 2 つのステップで行われる：

1）最小支持度を満たすアイテムの組合せを 全て見つける。これらを頻出アイテム集 合と呼ぶ.

2) 頻出アイテム集合から最小確信度を満た 
す相関ルールを全て求める.

第 1 ステップでは，トランザクション数が 多くなると組合せ可能なアイテムのバリエー ションが増えるため，ルールの支持度の計算 量も爆発的に増大寸る。第 2 ステップは，第 1 ステップで得られた頻出アイテム集合に対 するフィル夕処理に過ぎないため計算負荷は 比較的少ない。このため，第 1 ステップの処 理を効率化するための研究が盛んに行われて いる。中でも Agrawal らが提案した Apriori アルゴリズム[7]は, 現在最も広く利用されて いるアルゴリズムであり，本研究でもこれを 用いる。

\section{2 アーティスト相関ルール}

アーティスト相関ルールは，例えば " $\{$ Artist1 \& Artist2 $\} \Rightarrow\{$ Artist3 $\}$; 支持度 $=0.05$, 確信度 $=0.7 ”$ のように表される. これは, “Artist1, Artist2, Artist3 の3人 のアーティストを好む人は全体の $5 \%$ であり， さらにArtist1 とArtist2 を好む人の $70 \%$ は Artist3を好んでいる”ことを意味する。こ れにより，ユーザが Artist1 と Artist2 を好 むならば，Artist3も好む可能性が高いと考 え, Artist3 を推奨アーティストとしてユー ザに提示する，我々は，上記のようなルール にアーティストに対する嗜好理由を表す情報 を導入し，ユーザの嗜好性をより詳細に反映 した相関ルールへ拡張する (3 章参照).

\section{3 相関ルールを用いたアーティス 卜推奨の利点}

\subsection{1 推奖システムとの親和性}

アーティスト間の関係を相関ルールで記述 することにより，アーティストに対する嗜好 パターンを直感的に理解しやすい形式で表現 し, また, ユーザに推奨するアーティストを容 易に導出することができる．また，エーザが 結論部に相当するアーティストをどの程度好 むかを支持度と確信度により見積もることが
できるため, 推奨アーティストのランキング 指標として利用できる。このように相関ルー ルは，推奨アーティストの導出やランキング を行う上で都合が良く，推奨システムとの親 和性も高い。

\subsection{2 オンライン推奨での計算時間}

現在, 最も有名な推奨システムである GroupLens $^{[3]}$ では, ユーザ間の嗜好性の類似 度は,アイテムに対する評価点を記述したユー ザプロファイル間の相関係数を用いて計算さ れる。この方法は高い推奨精度を持つことが 知られているが，ユーザ間の相関はユーザか らの推奨要求の後にしか計算できないため, オンラインでの計算量が多い。この計算量は データベース中の人数が増えるほど多くなる. 一方, 本研究は, アーティスト間の相関ルー ルをオフラインで生成するため, データベー ス規模によらずオンラインでの計算量が少な くて済む.

\section{3 方法}

本研究では，アーティスト嗜好を調査する ためのアンケートを実施し，これに基づいて アーティスト相関ルールのマイニングおよび, それらを格納するデータベース(アーティス ト相関ルールデータベース)の構築を行った。 以下，3.1 節では本研究で行ったアンケート 調査について述べ, 3.2 節に扔いてアーティス 卜相関ルールデータベースの設計方法につい て説明する． 3.3 節では，このデータベースを 用いたアーティストの推奖方法について説明 する。

\section{1 アーティスト嗜好に関するアン ケート調査}

アーティスト嗜好を特徵付ける要因を調べ るため, 25 人の男女を対象として“好みのアー ティスト”および，それらの“アーティストを 好む理由”に関する事前アンケートを行った。 “好みのアーティスト”については回答者がア 
表 1 アーティストを好む 19 個の理由 (カッコ内は具体例)

声質, 音域, 歌い方, メロディ(やさしい, 力強い), テンポ (曲の速度), リズム (パーカッションのパ ターン), 調 (曲の明るさ), 拍子 ( $3 / 4$ 拍子), 歌詞, 楽器の音色, 楽器の奏法, ジャンル, 顔, ス夕イ ル, ファッション, 性格, 人生観, パフォーマン ス, ジャケット

ンケート調査時に好んでいるアーティストも しくは過去に好んでいたアーティスト名を記 入してもらった。また，“アーティストを好む 理由”については，それらのアーティストのど のような点に惹かれているか(例えば, 楽曲の メロディやアーティストの容姿など)を自然 言語で具体的に記入するよう指示した。我々 は,このアンケート調査によって, 回答者か ら得られた好みの理由を人手によって整理し， 最終的に表 1 に示されるような 19 個の嗜好理 由に分類した。ここで，後述のアンケート調 査において特に具体例を挙げて教示した喏好 理由については，その一例を括弧内に示した。 表 1 において，いくつかの嗜好理由は楽曲の 特徵を表すものだが(例えば, “メロディ”や “テンポ”など), 楽曲は個々のアーティスト の個性を特徴付ける要因であり, 間接的に個 人のアーティスト嗜好にも関わっていると考 えられることから，ここではアーティストを 特徴づける要因として扱った。 以下, 本論文 では，それらの楽曲に関する特徵を含めた 19 個の嗜好理由を, アーティスト嗜好を特徴付 ける要因と見なす。

次に, 18 歳から 46 歳までの男女 295 人 (男 性 235 人，女性 60 人）を対象として, 事前ア ンケートと同様に，“好みのアーティスト”㧈 よび，それらの“アーティストを好む理由”を 調査するアンケートを行った。ただし, “アー ティストを好む理由”については，表 1 の 19 個の理由から該当するものをチェックするよ う回答者に指示した.これ以降, 本論文では, このアンケート調査を事前アンケート調査と 区別して，単にアンケート調查と呼ぶ。アン ケート調査結果のうち, 238 件を次節で述べ
るアーティスト相関ルールデータベースを作 成するためのトレーニングセットとして用い, 残りの 57 件を 5 章で述べるシステムの評価 実験のためのテストセットとして利用する。

\section{2 アーティスト相関ルールデータ ベース}

\section{2 .1 前処理}

アーティスト相関ルールのマイニングに先 立ち，前節の 238 件のアンケート調査結果を 図 1 (左)に示されるような数值デー夕に変換 した．図1(左)におけるアーテイストID は各 アーティストに一意に与えられる番号である. また，各アーティストに対する嗜好理由を 19 次元のベクトルとして表現する。ベクトルの 各次元は表 1 の 19 個の嗜好理由に対応し, 各 次元の要素は回答者に選択された場合に 1 , そ うでない場合には 0 を持つ. 以下，このべク トルを Taste Vector と呼ぶ. 2 章で述べた相 関ルールの定義に従い, 図1(左)のようなア ンケートの集計結果をトランザクションデー タベースと見なすと，トランザクションは各 回答者のアンケート結果に, アイテムはトラ ンザクションに含まれるアーティスト(アー ティスト ID) に対応づけられる。

\subsection{2 嗜好理由を導入したアーティスト相 関ルール}

図1(左)のような要素をもつトランザクシ ヨンデータベースから，アンケート回答者に よって同時に好まれる傾向にあるアーティス トの相関ルールを抽出する。図 1 の右上図に 抽出されるアーティスト相関ルールの例を示 す. 本研究では, 最小支持度 $=1 /$ 全トラン ザクション数, 最小確信度 $=0.0$ に設定し, 2 名以上の回答者から支持されるアーティス ト相関ルールを全て抽出した。ささらに，相関 ルールを構成するアーティストがアンケー 卜回答者にどのような理由で好まれているか を表現するため，相関ルールに Taste Vector を導入する. 例として, 3 人のアーティスト (Artist1, Artist2, Artist3) で構成される次の 

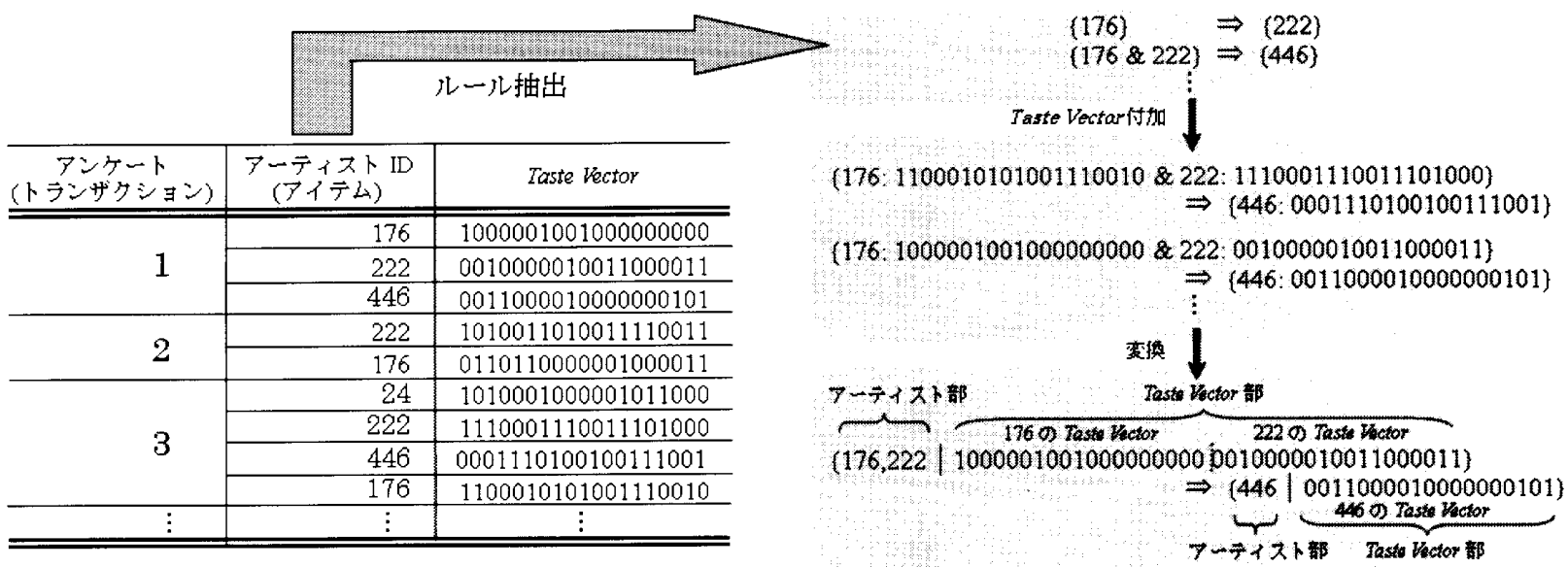

図 1 アンケート調査結果 (左) とアーティスト相関ルールの例 (右)

相関ルール

$$
\{\text { Artist1 \& Artist2 }\} \Rightarrow\{\text { Artist3 }\}
$$

が抽出された場合，相関ルールの条件部および 結論部に含まれるアーティストに対して各々 の Taste Vector を付加し，以下のような形式 で相関ルールを記述する (図 1 の右中図):

\section{$\{$ Artist1: TasteVector 1}

$$
\begin{aligned}
&\& \text { Artist2: TasteVector2 }\} \\
& \Rightarrow\{\text { Artist3: TasteVector3 }\}
\end{aligned}
$$

この相関ルールは, Artist1 とArtist2をそ れぞれ Taste Vector1 および Taste Vector2 の理由で好む人は, Artist3 Taste Vector3 の理由で好むことを意味する。ただし，計算 機上では，3.3 節で述べる推奨モジュールが Taste Vector に基づく検索ルールのランキン グを行う便宜上, 全ての相関ルールは図 1 の右 下図に示されるようにアーティスト部と Taste Vector 部に分けて記述される.

ここで，(3) のようなアーティスト嗜好パ ターンを持つ回答者が多数存在する場合には, それらの回答者間で個々のアーティストに対 する嗜好理由が異なる場合がある。このよう な場合, Taste Vectorの部分のみが異なる相 関ルールが複数生成されるが，本研究ではそ れらを別個の相関ルールであると見なす。

\subsection{3 データベース設計}

相関ルールの条件部に同じアーティスト ID を持つもの同士を同一のファイルに分類し，そ れらのファイルを格納するためのデータベース を作成した。データベースに格納されるファ イルの名称は, 条件部に含まれるアーティス トIDに応じて決定される。例えば，前項の (4) のような相関ルールを格納するファイル は，条件部に含まれるアーティスト名を用い て“Artist1_Artist2.txt”と名付けられる。こ のように，相関ルールの条件部のアーティス トに応じてファイルを分類することにより， 推奨モジュール (次節参照)によるルールの検 索時間を隇らすことができる。

\section{3 推奨方法}

前節で構築したデータベースからユーザの 好みに適合するアーティストを検索して提示 する, 以下の推奨モジュールを開発した。図 2 は, 推奨モジュールが行う処理の概要図であ る。推奨モジュールは，ユーザからのクエリ (推奨要求) として“好きなアーティスト”と “嗜好理由”を受け取ると，それらを“アーティ ストID”と“Taste Vector”に変換する，次に， ユーザの指定したアーティストIDを条件部に 持つ相関ルールを格納したファイルをデータ ベースから検索する。これにより，ユーザと同 じアーティストを好む人から得られたルール 


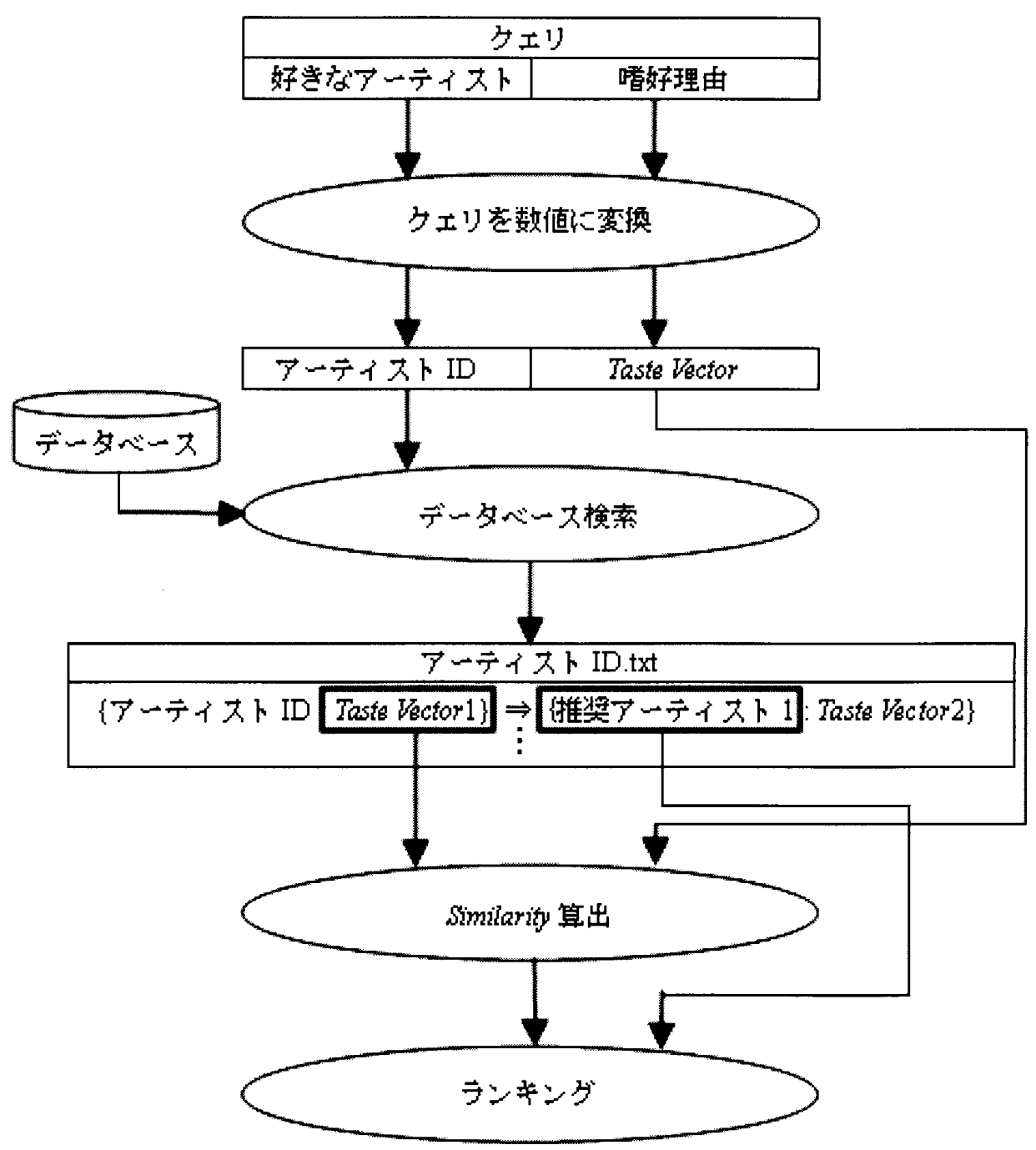

図 2 推奨モジュールの処理の概要図

のみが検索される．以下, 検索されたファイル に格納される相関ルール群を検索ルールと呼 ぶ. 最後に，ユーザの指定した Taste Vector と検索ルールの条件部が持つ Taste Vector を 用いて, 嗜好理由の類似度 (Similarity) を次 式により計算する：

$$
\text { Similarity }=\frac{\text { Count }_{\text {both }}}{\text { Count }_{\text {either or both }}}
$$

ここで, Count both $_{\text {はユーザの指定した }}$ Taste Vector と検索ルールの条件部の Taste Vectorの各次元において, 両方の值が 1 であ る個数, Count either or both $_{\text {は一方または両方 }}$ の值が 1 である個数を表す。高い Similarity を持つ検索ルールは，ユーザと嗜好理由の似
た人から得られた相関ルールであり，そのよう な人が好むアーティストはユーザにも好まれ る可能性が高いと考えられる。 そこで, 本研 究ではSimilarity の高い順に検索ルールの結 論部に含まれるアーティストをランク付けす る。ただし，同じSimilarityを持つ検索ルー ルが存在する場合には, 確信度 (confidence) の高い方を上位にランキングする。これによ り，ユーザの好みに合うアーティストほど，よ り上位にランキングされることが期待される。

\section{4 実行例}

3 章で説明した方法に基づき, Java 言語を 用いてシステムの実装を行った。図 3 は本シ 


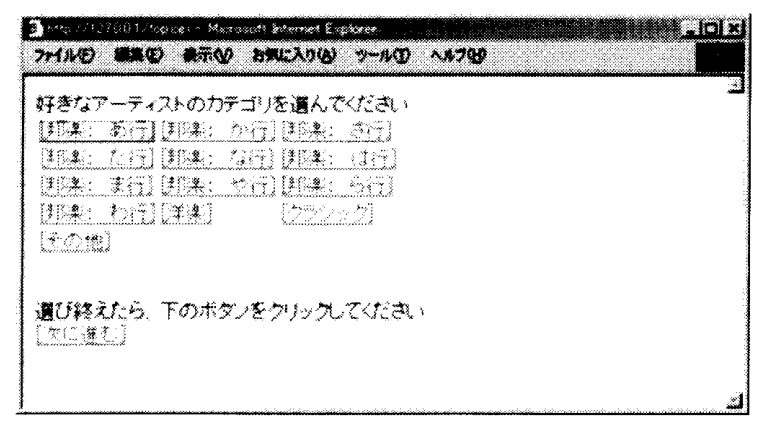

（a）カテゴリ選択

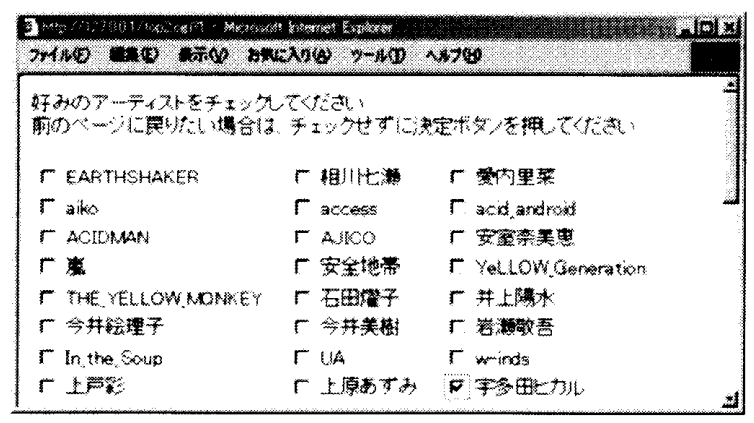

（b）アーティスト選択

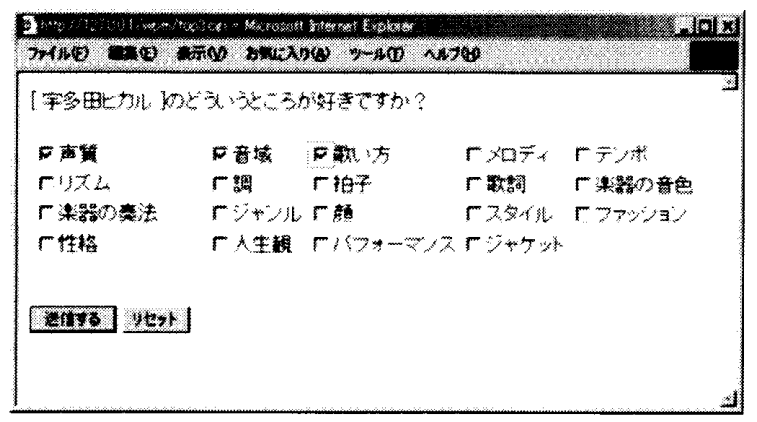

（c）畨好理由の選択

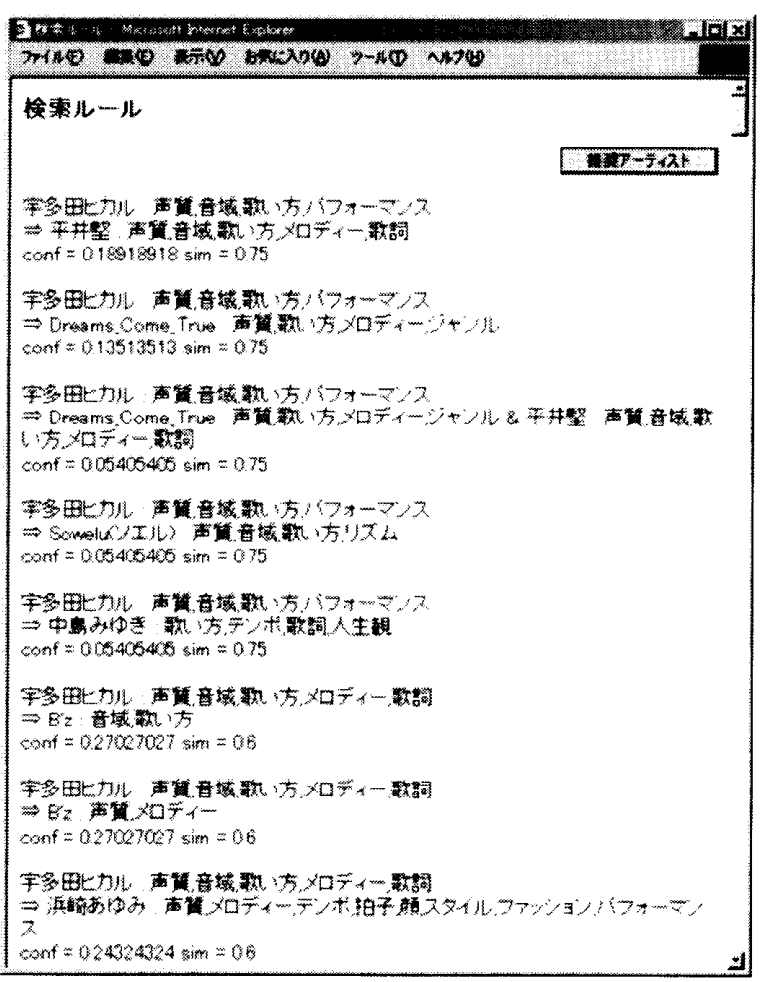

（d）検索ルール

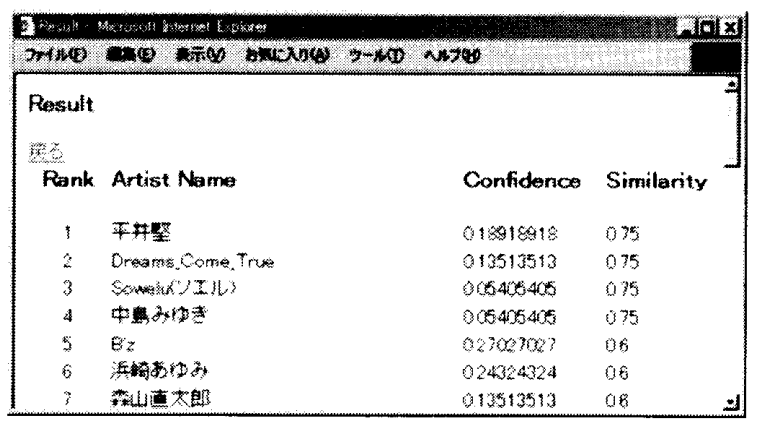

（e）推倸結果表示

図 3 本システムのスクリーンショット

ステムのユーザインターフェースおよびアー ティスト推奨画面のスクリーンショットであ る.ユーザはブラウザを介して, 以下の手順 で推奖要求を行う：

1) 好きなアーティストの頭文字 (邦楽) もし くはジャンル (洋楽, クラシック)を選択 する

2）好きなアーティストの名前を選択する

3）複数の好みのアーティストがいる場合に は，1）と2)の処理を繰り返す

4）1）から 3) までに指定したアーティスト
表 2 テストクエリとして使用したアーティスト名

B'z, 宇多田ヒカル, CHEMISTRY,

Mr. Children, aiko, 浜崎あゆみ, ゆず, 平井堅, 175R, Every Little Thing

毎に嗜好理由を選択する

5) 推奖モジュール実行ボタンを押し, 結果 を表示させる

以下，ユーザの好きなアーティストが“宇多田 ヒカル”であり, “声質”, “音域”, “歌い方”を 
好んでいる場合を例に本システムの使用方法 について説明する。ユーザはまず，図 3(a)の ウィンドウに拈いて “宇多田ヒカル”の頭文字 である“[邦楽：あ行]”を選択し，図3(b)のウィ ンドウから “宇多田ヒカル”を選択する，次に 図3(c)のウィンドウにおいて “声質”, “音域”, “歌い方”にチェックを入れ，推奨モジュール 実行ボタン ( “送信する”ボタン) を押す。そ の結果, 図 $3(\mathrm{~d})$ に示されるような検索ルール の表示ウィンドウが得られる．このウィンド ウにおいて“推奨アーティスト”ボタンを押す と, 図 3(e) に示されるような推奨結果が表示 される。ただし，図3(d) のウィンドウにおい て, 結論部に同じアーティストを含む検索ルー ルが複数存在する場合 (例えば Dreams Come True や B'z), その中で Similarity(図 3(d) に おける“sim”) が最も高い検索ルールのみが 残され，それ以外の検索ルールは削除される. ただし，最大の Similarityを持つ検索ルール が複数ある場合には，最大の確信度 (図 3(d) における“conf”）を持つ検索ルールのみを残 す.最終的に残った検索ルールは Similarity および確信度に基づいてソートされ，図 $3(\mathrm{e})$ のウィンドウに扔いて結論部のアーティスト がランキング表示される.

\section{5 システム評価実験}

本章では，テストクエリを用いて本システ ムの性能評価実験を行う。以下，5.1節では， 本実験で扱うテストクエリについて説明する. 5.2 節において推奨ランキングにおける Taste Vector の効果を検証し, 5.3 節では, 本システ ムと同じく相関ルールに基づく推奨システム である AR-CRS (Association Rules for Collaborative Recommender System $)^{[4][5]}$ との推 奨精度の比較を行う。 5.4 節では, オンライン 推奨およびオフラインでのデータベース構築 に要する計算量について議論する。

\section{1 テストクエリ}

3 章のアンケート調査で回答数の多かった
上位 10 名のアーティストをテストクエリと して用いる。表 2 にテストクエリとして使用 したアーティスト名を示す。我々は，3 章で 用意した 57 件のテストセットから, 各テスト クエリを含むアンケートを 1 枚ずつ抜き出し てテストアンケートとした。こうして得られ た 10 枚のテストアンケートには, テストクエ リ以外にアンケート回答者の好きなアーティ ストが複数記入されている。ここでは, 各テ ストアンケートにおいてテストクエリを除く 個々のアーティストをターゲットと呼ぶ。テ ストクエリを与えた時にターゲットが上位に ランキングされるならば，実際のシステムの 利用においても，ユーザにとって未知の好み のアーティストが上位にランキングされる可 能性が高いと考えられる，以下，本章ではテ ストクエリに対するターゲットの推奨精度に 基づいてシステムの評価実験を行う.

\section{2 推奨ランキングにおける Taste Vector の効果}

本システムの大きな特徵は, ユーザの指定 した嗜好理由 (Taste Vector) に基づいて推奖 アーティストをランキングする点にある。こ れによりユーザの好みに合ったアーティスト ほど上位にランキングされると期待される。 ここでは，テストクエリを用いて推奨ランキ ングにおける Taste Vector の効果を検証する.

\subsection{1 評価方法}

テストクエリを与えた時のターゲット推奨 順位の合計值により，システムの推奨ランキ ング精度を見積もる。つまり，ターゲットの 推奖順位の合計値が小さいほど，システムの 推奨ランキング精度が高いと考える. 我々は, 本システムの Taste Vector に基づくランキン グ精度を評価するため, 相関ルールの確信度 を用いたランキング精度との比較を行う。こ こで, 確信度に基づくランキング法とは, 検 索された相関ルールの確信度が高い順に結論 部のアーティストを提示する方法である. 
表 3 各テストクエリに対するターゲッ トの推奨順位合計

\begin{tabular}{lcc}
\hline & \multicolumn{2}{c}{ 推奨順位合計 } \\
\cline { 2 - 3 } テストクエリ & Taste Vector & 確信度 \\
\hline \hline B'z & $\underline{102}$ & 112 \\
宇多田ヒカル & 183 & $\underline{179}$ \\
CHEMISTRY & $\underline{63}$ & 73 \\
Mr. Children & $\underline{30}$ & 43 \\
aiko & $\underline{75}$ & 78 \\
浜崎あゆみ & 61 & $\underline{46}$ \\
ゆず & $\underline{80}$ & 114 \\
平井堅 & $\underline{32}$ & 41 \\
175R & $\underline{46}$ & 48 \\
Every Little Thing & 77 & $\underline{76}$ \\
\hline
\end{tabular}

\subsection{2 結果}

表 3 に 10 個のテストクエリに対するター ゲット推奨順位の合計值を示す．表中の下線 を引いた值は，各テストクエリに対する夕ー ゲットの推奨ランキング精度が高い方 (ター ゲット推奨順位の合計值が小さい方) を示し ている。結果として，7個のテストクエリにお いて本システムの推奨ランキング精度が勝っ ており，Taste Vectorがターゲットのランキ ングに有効に機能していると考えられる.

確信度はトレーニングセット中での相関 ルールの統計的な重要度を表しているに過ぎ ないため，ランキング結果が必ずしも個々の ユーザ (テストアンケートの回答者)の好みを 反映するとは限らない。一方，本システムは 検索された相関ルールの持つ Taste Vector と ユーザの指定した Taste Vector との類似度に したがってランキングを行う。従って，ユー ザの嗜好理由を直接ランキングに反映できる ため，ユーザの好みに合ったアーティストを より上位にランキングできると考えられる。

\subsection{AR-CRS との推奨精度の比較}

AR-CRS は相関ルールに基づく推奨システ ムとして, Lin らによって提案された[4][5]。彼 等は,アイテム相関法，ユーザ相関法，アイテ ム相関ーユーザ相関を融合した方法の 3 つの手
法を提案しており，中でも，ユーザ相関法はこ れらの手法で最も高い推奖精度を持ち, さら に, GroupLens ${ }^{[3]}$ の推奨精度を大幅に上回る ことを示している。そこで本節では $\mathrm{AR}-\mathrm{CRS}$ のユーザ相関法 (以下，AR-CRS) を比較対象 として, 本システムの性能評価を行う。

\subsection{1 評価方法}

評価指標として，情報検索システムの標準 的な性能評価基準である適合率 (precision) と 再現率 (recall) を用いる。ここで, 各テスト クエリに対するターゲット数を $R$ とする。ま た，テストクエリに対して推奨された全アー ティスト数を $n$, 正しく推奨されたターゲッ 卜数を $r$ とする。この時, 適合率は $r / n$, 再 現率は $r / R$ で定義される。つまり，適合率は 推奨されたアーティストのうち正しく推奨さ れたターゲットの割合であり，再現率はテス トクエリに対するターゲットのうち正しく推 奨されたターゲットの割合を表す。評価は, 全てのテストクエリに対する適合率および再 現率を平均し, 再現率-適合率グラフ $[8]$ を作成 することにより行う。再現率-適合率グラフ とは, 横軸に再現率を 0.1 刻みの 11 個の点 $(0.0,0.1, \ldots, 1.0)$ でとり，それに対する適合 率を縦軸にプロットしたグラフである。この グラフが右上に位置するほど性能 (推奨精度) が高いと見なす。

\subsection{2 結果}

図 4 に再現率一適合率グラフを示寸。なお, 図には本システムと AR-CRS の他に，5.2 節 で述べた確信度に基づくランキング法の再現 率-適合率グラフも示した。ここで，いずれの グラフも再現率が 1 に達していないのは, ター ゲットを含む相関ルールが最小支持度に満た ないためにマイニング処理において除去され たか，あるいはターゲットがデータベースに 存在していない(トレーニングセットに無い) ケースがあったためである，図に示されるよ うに，本システムは再現率-適合率グラフを用 いた推奨精度において，AR-CRS や確信度に 基づくランキング法を上回る結果となった。 


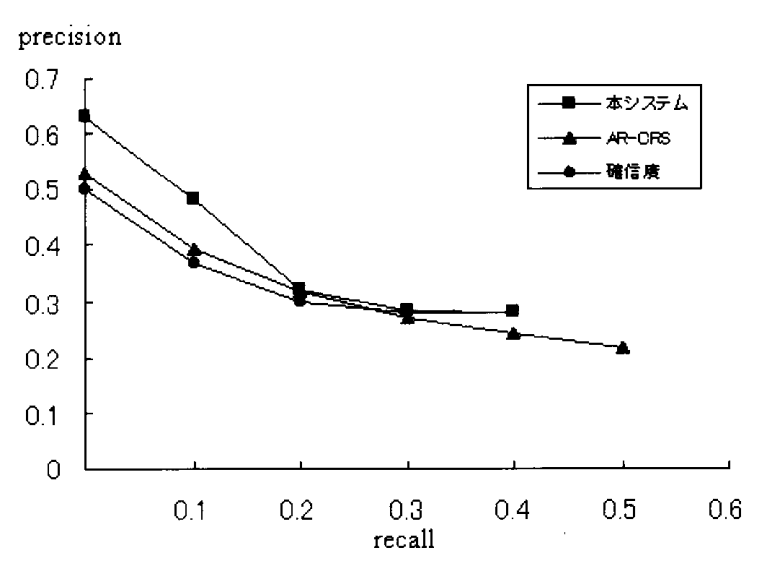

図 4 再現率一適合率グラフ

\section{4 計算量に関する議論}

図 5 は, 本システム, AR-CRS および GroupLens に扔けるオンライン推奨に要する 計算量の比較結果である。ここでは, 計算量 として推奨時に打けるデータベースへのアク セス回数を用いた．各システムのデータベー スは 3.1 節の 238 件のアンケートデータをも とに作成した。図 5 の横軸はアンケートの回 答者数 $(50,100,150,200,238$ 人), 縦軸は 5.1 節の 10 個のテストクエリを各システムに与え た時の平均アクセス回数である。図 5 に示さ れるように, 本システムの計算量は AR-CRS に比較して格段に小さいことがわかる。これ は, AR-CRSが推奨時にリアルタイムに相関 ルールマイニングを行う必要があるのに対し， 本システムでは予めオフラインでアーティス ト間の相関ルールを生成し,オンラインでは 推奨ルールの検索に要する計算時間で済むた めである. GroupLens との比較では, 計算量 はさほど変わらないが，これは，アンケート で最も回答者数が多かったアーティストをテ ストクエリとしたためである。アンケートで 回答者数が多いアーティストを条件部に持つ ルールは, 回答者数が少ないアーティストと 比較して多く存在する傾向があり，推奨時の データベースへのアクセス数が多くなってし まう。これは本システムにとって最も不利な 状況での比較を意味している，そこで，テス トクエリ以外のアーティストも考慮に入れた

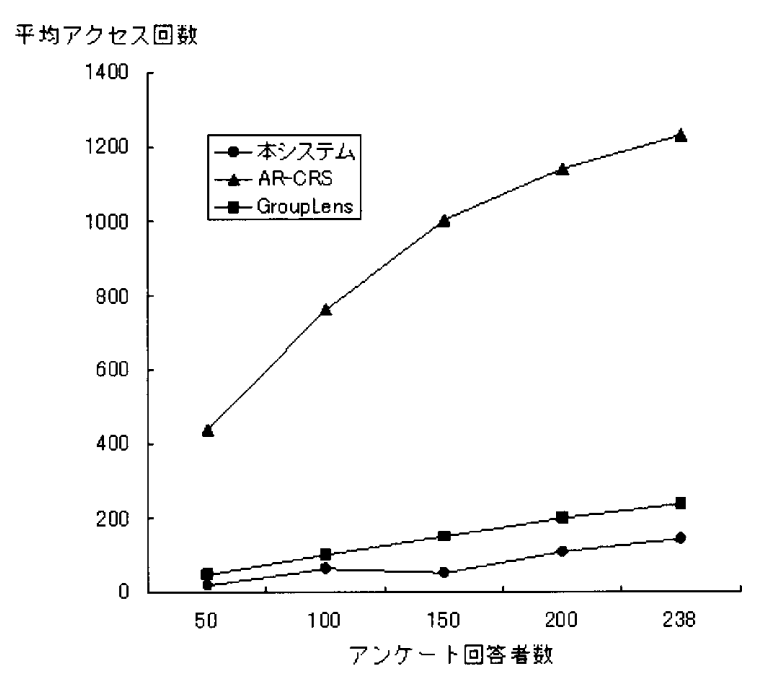

図 5 オンライン推奨における計算量

場合に，図 5 の横軸に示したユーザ数で生成 される平均ルール数を計算した。 その結果, それぞれ平均で $7,9,9,10,11$ 個であり，い ずれも GroupLens のアクセス数に比較して十 分小さな值となった。これは，本システムが GroupLensよりも，ユーザ数に対する計算量 の増加が緩やかであることを示している。

一方, オフラインでのデータベース構築に必 要な計算量については, AR-CRS と GroupLensについては0であるのに対し，本システ ムではアーティスト相関ルールのマイニング に必要な計算量を要する。例えば，本論文で 使用した 238 件のアンケートデー夕を対象と した場合の計算時間は, 1.6 秒 (Pentium IV, $3.2 \mathrm{GHz}, 1.0 \mathrm{~GB} \mathrm{RAM})$ であった。しかし，こ こで扱ったような少ないデー夕数では現実的 な時間内で計算可能だが,デー夕数が数千・数 万オーダーの場合にはオフライン計算量の負 荷が深刻な問題となってくる．また，本システ ムでは新たなユーザを追加する度に相関ルー ルデータベースを再構築するための計算が必 要となることが欠点である。

\section{6 まとめ}

本論文では，ユーザの好きなアーティスト とその嗜好理由に基づいて，ユーザの嗜好性 に合ったアーティストを推奨するシステムを 
提案した。本システムの評価実験から，アー ティストに対する嗜好理由をクエリに取り入 れることで，ターゲットをより上位にランキ ングできること，また，相関ルールに基づく 推奨システムである AR-CRS との性能比較 において，本システムの方が高い推奨精度を 持つことを示した。さらに，本システムは， AR-CRS や GroupLens よりもオンライン推 奨における計算量が少ないことを示した。

一方, 本研究で使用した 19 個の嗜好理由は 事前アンケートに基づいて我々が手作業で決 定したもので，それらが実際に個人の嗜好を 特徴付ける要因として妥当かどうかの検証は 行っていない。アーティス卜嗜好に関わる特 徵量を心理学的あるいは統計的分析をとおし てさらに吟味し，推奨技術に取り入れていく ことは今後の課題である。また，実装システ ムはクエリの入力毎に嗜好理由を要求するた め, ユーザが入力すべき項目が多くなってしま うことが大きな問題となる。そのようなユー ザの負担を軽減するためには，例えば，入力 アーティストのみからユーザの嗜好プロファ イル (入力アーティストに対する嗜好理由)を 推定する機構を導入するなどの工夫が必要に なるであろう。

ユーザの感性にあった推奨を行う上で, ユー ザがアイテムに抱いている印象を考慮するこ とは非常に重要な観点である，矢野らは，人 がアイテムを観察・評価し，取捨選択するまで の段階的なプロセスを，「ザラザラした」，「か わいい」のような印象語を用いてモデル化(イ メージ語ネット[9])し，推奨システムへの適用 を試みている。一方，本論文では，ユーザが アイテムの “どの” 側面を評価して好んでい るか，すなわち，「リズム (が好き)」，「顔 (が 好き)」といったユーザの感性を反映する具体 的な嗜好理由の個人差を考慮した推奨方法を 提案した。

アーティストに限らず香水や絵画など, 様々 なコンテンツに対する嗜好性には，個人の感 性が大きく関与していると考えられる。近年, オンラインショッピングの普及に伴い，イン ターネット上で購入できる商品の種類や数が
急激な増加を見せている。そのような膨大か つ多種多様な商品から，本論文で述べたよう な，ユーザの感性的な喏好性に基づいて商品 推奨を行う技術の開発は，今後ますます重要 になると思われる。

\section{参考文献}

[1] "Amazon.co.jp", http://www.amazon. co.jp/ (2005 年 2 月 21 日参照)

[2]「楽天市場」, http://www.rakuten.co.jp/ (2005 年 2 月 21 日参照)

[3] Resnick, P.; Iacovou, N.; Suchak, M.; Bergstorm, P. and Riedl, J.: "GroupLens: An Open Architecture for Collaborative Filtering of Netnews", Proc. ACM Conf. on computer Supported Cooperative Work, Chapel Hill, North Carolina, pp.175-186, 1994

[4] Lin, W.; Alvarez, S. A. and Ruiz, C.: "Collaborative Recommendation via Adaptive Association Rule Mining", Proc. Web Mining for E-Commerce Workshop, Boston, 2000

[5] Lin, W.; Ruiz, C. and Alvarez, S. A.: "A New Adaptive-Support Algorithm for Association Rule Mining", Technical Report WPI-CS-TR-00-13, Department of Computer Science, Worcester Polytechnic Institute, 2000

[6] Agrawal, R.; Imielinsi, T. and Swami, A.: "Mining Association Rules between Sets of Items in Very Large Databases", Proc. ACM, SIGMOD, Int. Conf. Management of Data, Washington, D.C., pp.207-216, 1993

[7] Agrawal, R. and Srikant, R.: "Fast Algorithms for Mining Association Rules in Large Databases", Proc. 20th Int. Conf. Very Large Data Bases, Santiago, Chile, pp.487-499,1994

[8] Harman, D. K.; editor: "Overview of the Third Text Retrieval Conference 
(TREC-3)", National Institute of Standards and Technology, Gaithersburg, MD, 1995

[9] 矢野絵美; 北野有亮; 末吉恵美; 篠原勲; ピ ンヤポンシニーナット;加藤俊一:「消費者 の感性モデルを利用したレコメンデーシ
ヨンシステムの構築」, 情報処理学会論文 誌, 44, SIG08(TOD18), pp.46-53, 2003

(2005 年 2 月 24 日受付) (2005 年 7 月 21 日採択) 